\title{
Basin-scale coherence of population dynamics of an exploited marine invertebrate, the bay scallop: implications of recruitment limitation
}

\author{
Charles H. Peterson, Henry C. Summerson \\ University of North Carolina at Chapel Hill, Institute of Marine Sciences, Morehead City, North Carolina 28557, USA
}

\begin{abstract}
Direct effects of a red tide (Ptychodiscus brevis) outbreak on bay scallops Argopecten irradians concentricus in North Carolina, USA, from October 1987 to February 1988 were necessarily limited to the 2 generations then present (adults of the year-class fished in winter $1987-88$ and their progeny harvested in 1988-89), yet the 3 subsequent year-classes of bay scallops (those fished in the 1989-90,1990-91, and 1991-92 winter seasons) also have been extremely depressed. The fishery crashed to about 10 to $15 \%$ of the recent ( $25 \mathrm{yr}$ ) historical average harvest: no recovery has yet begun. This inability to recover quickly along with evidence of a previous gradual ( 5 to $12 \mathrm{yr}$ ) though erratic recovery from low population size in the early 1970's implies that this scallop population may be recruitment-limited at low density. Sampling of adults in August just before spawning and of new recruits surviving until early December in both 1988 and 1989 revealed that recruitment was positively related to adult abundance. This relationship was assessed across 9 bay scallop grounds in North Carolina. Settlement onto spat collector bags deployed at these sites during early autumn also tended to follow the same patterns of adult and recruit abundance among sites in 1988 but not in 1989. Patterns of adult and recruit abundance were broadly coherent across water bodies, with densities in Core Sound high, Back Sound relatively low, and Bogue Sound extremely low. Compared to identical sampling conducted during 3 years just preceeding the red tide outbreak, average autumn recruitment rates of bay scallops for 1988 and 1989 were normal in Core Sound, about $29 \%$ of normal in Back Sound, and about $5 \%$ of normal in Bogue Sound. This pattern continues to conform to the documented pattern of immediate direct effects of the red tide. Changes in area of its seagrass habitat appear incapable of explaining the sound-specific pattern of bay scallop declines following the red tide. This coherence of population dynamics on a basin scale implies that the bay scallop may be recruitmentlimited at low density by mesoscale or sound-wide abundance of spawning adults, creating lasting effects of the red tide propagated through basin-scale population inertia. Recruitment limitation for an exploited species would have important consequences for sustainability of harvest, if based on an effective stock-recruitment relationship, and may imply need for management intervention to enhance spawning stock within depleted basins.
\end{abstract}

\section{INTRODUCTION}

One of the most important and wide-reaching advances in marine ecology of the past few years is the realization that limited larval settlement may be responsible for several dramatic patterns both in population abundance and structure and also in community organization (e.g. Underwood \& Denley 1984, Gaines \& Roughgarden 1985, Doherty \& Williams 1988, Roughgarden et al. 1988). Under conditions of what has become known as recruitment limitation, patterns of population abundance in some specified system vary as a function of the numbers of successful larval colonists, rather than being set by subsequent postsettlement processes such as competition for limited resources or predation. Evidence of such recruitment limitation now exists for some marine fishes (Doherty 1983, Warner \& Chesson 1985, Victor 1986, Shulman \& Ogden 1987, Doherty \& Williams 1988), corals (Sammarco \& Andrews 1989), sea urchins (Karlson \& 
Levitan 1990), bryozoans (Yoshioka 1982, Hughes 1990), and barnacles (Gaines \& Roughgarden 1985, Sutherland 1987). Despite this wide range of examples of possible recruitment limitation among marine animals, no study has explicitly addressed whether recruitment limitation applies to marine invertebrates occupying soft-bottom habitats (although see Woodin 1976, Peterson 1979) nor have the implications of recruitment limitation to invertebrate fisheries management been adequately explored.

Processes that control community dynamics in marine soft-sediment systems seem to differ rather markedly from those organizing communities of invertebrates on hard substrata (Peterson 1979, 1991. Wilson 1991), so any extrapolation from results of studies on rocky-shore or coral-reef invertebrates must be carefully justified. Many of the invertebrate species that are commercially exploited in large quantities reside in or on soft bottoms. Consequently, expanding study of the role of recruitment limitation to include soft-bottom invertebrates has both intrinsic and practical importance. An almost universal assumption of shellfisheries management is that spawning marine invertebrates release so many larvae that subsequent year-class strength is not limited by spawning stock size or by abundance of larvae released (Hancock 1973). This assumption does not necessarily conflict with recruitment limitation in that recruitment limitation could be entirely driven by water-column processes that produce larval mortality. Nevertheless, to the degree that recruitment limitation exists and is related to spawning effort in any exploited stock, there are important implications for management. Thus, a test of whether recruitment limitation operates in exploited marine invertebrate populations of soft-sediment habitats is overdue.

Summerson \& Peterson (1990) suggested that the dynamics of the bay scallop Argopecten irradians concentricus population over a 21 yr period in North Carolina (USA) were consistent with the assumption that population size was recruitment-limited and related at low population sizes to low spawning stock biomass. Recovery of population size from a severe crash in 1970 had been slow, although erratic, taking 5 to 12 yr to reach the $1965-66$ levels and not yet achieving the 1967-68 levels by 1987, when the first documented red-tide outbreak in coastal North Carolina caused another catastrophic decline to abundances as low as those of the early 1970's (Summerson \& Peterson 1990). Here we provide observations on how the bay scallop population has recruited in the years following the red-tide event and present evidence that the failure to recover quickly to previous levels of abundance may be related to the dependence of scallop recruitment on adult spawner abundance on a basin scale, implying recruitment limitation based on low spawning effort at low population sizes and a need for evaluating potential management tools to enhance the naturally slow recovery.

\section{METHODS}

The species. Like other scallops (e.g. see Dickie 1955, Orensanz 1986, Wolff 1988), the bay scallop in North Carolina possesses several characteristics that facilitate its use in studies of population processes (Peterson 1990). The species exhibits essentially an annual life history with a longevity of 12 to $18 \mathrm{mo}$, rarely up to $30 \mathrm{mo}$ (Belding 1910, Gutsell 1930). This rapid alternation and relatively unambiguous separation of generations (e.g. see Peterson et al. 1989) permits direct testing for the presence of relationships between generations by use of the fishery catch statistics for each separate winter fishing season. The commercial fishery for bay scallops in North Carolina has been prosecuted almost identically every year during the past quarter century, with a season opening in December and closing in spring after adult scallops have been depleted to a point that commercial fishing is no longer economically viable (Kellogg \& Spitsbergen 1983, Peterson 1990). This fishery harvests only a single year-class of adult scallops. Consequently, the seasonal catch statistics represent reasonable indices of total population size of a single adult generation in a fixed season, the winter. The only serious departures from this procedure in the past $25 \mathrm{yr}$ occurred during 1987-88, when concern for contamination of meats by red-tide toxins delayed opening of the 1987-88 winter scalloping season until March 1988, and during 1988-89, when concern for protection of juvenile scallops from possible habitat damage during fishing on depressed adult stocks delayed opening of the 1988-89 scalloping season until midJanuary 1989. Even for the 1987-88 and 1988-89 seasons, the commercial catch is probably a reasonable estimate of winter adult stock abundance because the red tide had caused such extensive bay scallop mortality (Summerson \& Peterson 1990) that a longer fishing season would not have yielded much added effort or harvest.

Most bay scallops in North Carolina are produced from an August-September spawning by adults (Sastry 1966, Peterson et al. 1989). The planktotrophic larvae are presumed to spend about 5 to $11 \mathrm{~d}$ developing in the water column before settlement, as judged from the development times in hatcheries (Castagna \& Duggan 1971, Castagna 1975). Adult bay scallops live only within the sounds, not offshore, and only where salinities remain above about $20 \%$ (Gutsell 1930). It is presumed (but not demonstrated) that the larvae com. 
plete their development within the sounds. Settlement occurs onto hard substrata, predominantly seagrass blades in North Carolina (Gutsell 1930, Thayer \& Stuart 1974). The juvenile bay scallops remain attached by byssus to the seagrass blades for 2 mo (Argopecten irradians irradians: Pohle et al. 1991) to perhaps 4 mo (A. i. concentricus: Castagna 1975, pers. obs.) until they reach a size of 20 to $25 \mathrm{~mm}$. These scallops then fall to the estuarine seafloor, remain in the seagrass beds, and grow rapidly when waters warm. A. i. concentricus spawn as adults in late summer-early autumn and die off gradually over winter with few surviving until spring (see Gutsell 1930), Some additional scallop spawning is inferred to occur around May (Peterson et al. 1989), presumably by those individuals that have survived their second winter. However, it seems also possible that some rapidly growing scallops from the late spring or late summer spawn may reach maturity in time to release gametes in the next spring.

Field sampling of bay scallops. To test for potential relationships among scallop beds between adult bay scallop abundance and local recruitment intensity and also to test whether spatial patterns of bay scallop abundance detectable at the recruit stage persist into adulthood, we sampled both adult bay scallops and recruits in 1989 and 1990 . These represent the years immediately following the 1987-88 red tide, so our data on abundance of bay scallops also document the scope and pattern of recovery by contrast to our own sampling data taken prior to the red tide using identical methodologies (Summerson \& Peterson 1990). Sampling was achieved by taking between 35 and 61 stratified haphazard $0.5 \mathrm{~m}^{2}$ samples at each of several sites (Table 1). A suction dredge was used to vacuum clean cylindrical samples formed by $6 \mathrm{~mm}$ mesh attached to a metal hoop at the bottom and to a buoyant hoop on top, isolating the water column overlying each $0.5 \mathrm{~m}^{2}$ bottom plot. Details of sampling methods are described in Summerson \& Peterson (1990); the high efficiency of this sampling technique is demonstrated in Peterson et al. (1989).

During each year, the field sampling to estimate bay scallop densities was conducted at each of 9 bay scallop grounds during August prior to spawning, to assess abundance of adults, and again in December after settlement but before opening of the fishery, to assess recruitment success (Table 1). Each bay scallop collected during sampling was measured with vernier calipers to the nearest $0.1 \mathrm{~mm}$ from the umbo to the ventral margin (height). Size measurements permitted us to separate the scallops into adults and recruits, using a cutoff of $4 \mathrm{~cm}$ (as in Peterson et al. 1989), which separates the 2 modes unambiguously at both of these dates. Because we sampled 2 successive years, we also could test whether the patterns of intensity of bay scallop recruitment among scallop grounds continued to be reflected in abundance of adults a year later, as would be expected if recruitment limitation were operating.

The sampling sites were chosen to include all the traditionally most productive bay scallop fishing grounds of the state and to cover the complete geographic range of commercially viable accumulations of bay scallops. Two of the sampling sites fail to meet the criterion of being significant scalloping grounds but were chosen to complete the geographic coverage of specific water bodies to judge the scale of larval dispersal: Pine Knoll Shores was chosen to provide information from near the eastern end of Bogue Sound, and Middle Marsh to sample the western end of Back Sound. This distribution of 9 sampling sites (Fig.1) ranged across 4 sounds from Pamlico Sound in the north through Core and Back Sounds to the western end of Bogue Sound in the south. Five of these sites were included in

Table 1 Scope in time and space of the field samplings done to estimate densities of bay scallops Argopecten irradians concentricus. Entries in the table are specific sampling dates and (in parentheses) numbers of replicate $0.5 \mathrm{~m}^{2}$ samples taken. -: No sampling conducted at that time and place. See Fig. 1 for locations of sampling sites

\begin{tabular}{|c|c|c|c|c|c|c|c|c|c|}
\hline \multirow[t]{3}{*}{ Date } & \multicolumn{9}{|c|}{ Site } \\
\hline & \multirow{2}{*}{$\begin{array}{c}\text { Pamlico Sound } \\
\text { Ocracoke }\end{array}$} & \multirow{2}{*}{$\begin{array}{l}\text { Core Sound } \\
\text { Yellow Shoal }\end{array}$} & \multicolumn{3}{|c|}{ Back Sound } & \multicolumn{4}{|c|}{ Bogue Sound } \\
\hline & & & $\begin{array}{c}\text { Banks } \\
\text { Bay }\end{array}$ & $\begin{array}{l}\text { Bald Hill } \\
\text { Bay }\end{array}$ & $\begin{array}{l}\text { Middle } \\
\text { Marsh }\end{array}$ & $\begin{array}{c}\text { Pine Knoll } \\
\text { Shores }\end{array}$ & $\begin{array}{l}\text { Dog } \\
\text { Island }\end{array}$ & $\begin{array}{l}\text { Salter } \\
\text { Path }\end{array}$ & $\begin{array}{l}\text { Emerald } \\
\text { Isle }\end{array}$ \\
\hline Aug 1988 & $\begin{array}{c}23 \mathrm{Aug} \\
(61)\end{array}$ & $\begin{array}{l}5 \text { Aug } \\
\text { (57) }\end{array}$ & $\begin{array}{l}9 \text { Aug } \\
(62)\end{array}$ & $\begin{array}{l}8 \text { Aug } \\
(59)\end{array}$ & - & - & - & - & $\begin{array}{l}4 \mathrm{Aug} \\
\text { (59) }\end{array}$ \\
\hline Dec 1988 & $\begin{array}{l}7 \mathrm{DeC} \\
(59)\end{array}$ & $\begin{array}{c}30 \text { Nov } \\
\text { (57) }\end{array}$ & $\begin{array}{c}21 \text { Nov } \\
(56)\end{array}$ & $\begin{array}{l}2 \mathrm{Dec} \\
(56)\end{array}$ & $\begin{array}{c}29 \text { Nov } \\
(58)\end{array}$ & $\begin{array}{l}1 \mathrm{Dec} \\
(39)\end{array}$ & $\begin{array}{l}1 \mathrm{Dec} \\
(35)\end{array}$ & $\begin{array}{l}1 \mathrm{DeC} \\
(40)\end{array}$ & $\begin{array}{c}22 \text { Nov } \\
\text { (59) }\end{array}$ \\
\hline Aug 1989 & $\begin{array}{l}3 \text { Aug } \\
(59)\end{array}$ & $\begin{array}{l}4 \text { Aug } \\
(60)\end{array}$ & $\begin{array}{l}9 \text { Aug } \\
(56)\end{array}$ & $\begin{array}{c}10 \mathrm{Aug} \\
(61)\end{array}$ & $\begin{array}{l}4 \text { Aug } \\
(56)\end{array}$ & $\begin{array}{l}2 \text { Aug } \\
(41)\end{array}$ & $\begin{array}{l}2 \text { Aug } \\
(39)\end{array}$ & $\begin{array}{l}2 \text { Aug } \\
\text { (39) }\end{array}$ & $\begin{array}{l}1 \text { Aug } \\
\text { (59) }\end{array}$ \\
\hline Dec 1989 & $\begin{array}{l}4 \mathrm{Dec} \\
(60)\end{array}$ & $\begin{array}{c}27 \text { Nov } \\
(61)\end{array}$ & $\begin{array}{l}1 \mathrm{Dec} \\
(57)\end{array}$ & $\begin{array}{c}30 \text { Nov } \\
\text { (59) }\end{array}$ & $\begin{array}{c}29-30 \text { Nov } \\
(58)\end{array}$ & $\begin{array}{l}3 \mathrm{Dec} \\
(38)\end{array}$ & $\begin{array}{l}3 \mathrm{Dec} \\
(39)\end{array}$ & $\begin{array}{c}28 \text { Nov } \\
\text { (43) }\end{array}$ & $\begin{array}{c}28 \text { Nov } \\
(60)\end{array}$ \\
\hline
\end{tabular}




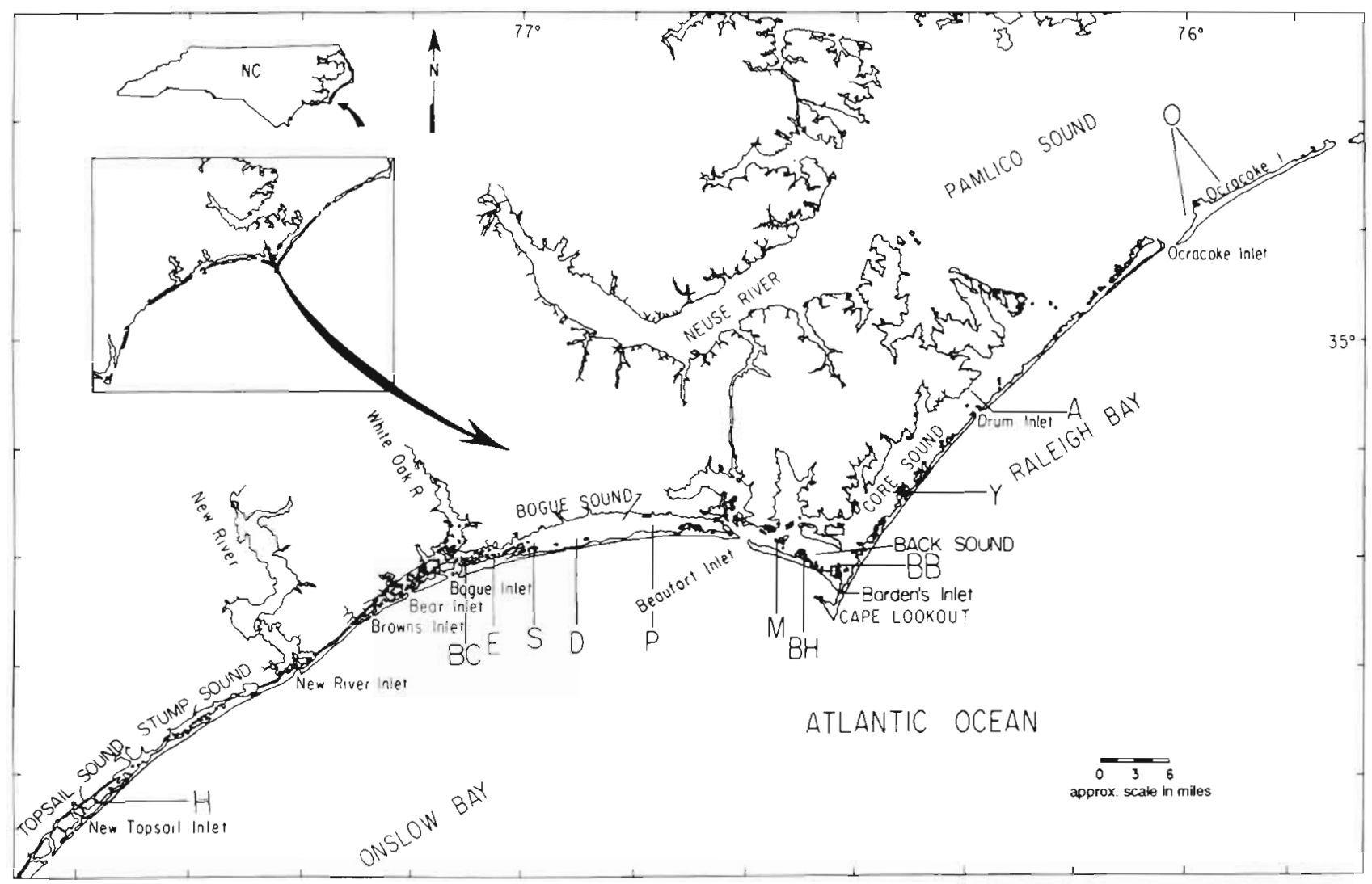

Fig. 1. Cape Lookout region of the central North Carolina coast, showing the distribution of bay scallop sampling sites and sites for deployment of scallop spat collectors among the 5 sounds: Ocracoke (O), Atlantic (A), Yellow Shoal (Y), Banks Bay (BB), Bald Hill Bay (BH), Middle Marsh (M), Pine Knoll Shores (P), Dog Island (D), Salter Path (P), Emerald Isle (E), and Hampstead (H). Sites for the juvenile seeding experiment were small embayments at Middle Marsh and Burden Channel (BC)

our previous sampling (Summerson \& Peterson 1990), permitting direct contrasts over time.

The duration and intensity of the 1987-88 red tide (Ptychodiscus brevis) bloom was much greater at the southern end of the bay scallop range in North Carolina than at its northern end (see extensive account in Tester et al. 1991). The bloom was seeded by a Gulf Stream filament detectable in satellite imagery on 19 October 1987. Bloom conditions were observed on the ocean side of Bogue Banks (Fig. 1) by 31 October. Tidal exchange then inoculated the sounds, with the highest cell counts in the sounds found just inside those inlets (Bogue Inlet, Beaufort Inlet, and Barden's Inlet) that connect to Onslow Bay (Tester et al. 1991). From 3 November 1987 until 6 February 1988, counts ranged from 5000 to 500000 cells $1^{-1}$ throughout Bogue and Back Sounds. In contrast, cell counts were negligible from Yellow Shoal northward in Core Sound until 13 November. P. brevis had disappeared from Core Sound by 28 December and even during this $6 \mathrm{wk}$ period of presence it never attained the high concentrations observed in Bogue and Back Sounds (Tester et al. 1991). As a consequence of the differing intensity and duration of the red tide, bay scallop mortality and recruitment failure was largely limited to Bogue and Back Sounds (Summerson \& Peterson 1990). As is the case for other examples from toxic and nuisance algal blooms, the mechanism by which invertebrate recruitment was inhibited has not been established: it may have involved interference with fertilization or embryo development (see Granmo et al. 1988) but, whatever the mechanism, effects of the red tide would not be expected to persist beyond the life spans of the 2 generations directly affected. Consequently, the 1989 and 1990 sampling done to evaluate recovery of the bay scallop populations after the red tide and reported here (1) extends our previous sampling to include subsequent generations not directly affected by the red tide, and (2) assesses the degree to which the bay scallop exhibited regionally coherent population dynamics within regions inside the 4 -sound system.

Deployment of spat collectors to assess settlement patterns. To enhance our understanding of the population dynamics of bay scallops, we deployed spat collectors to estimate spatial and temporal patterns in bay 


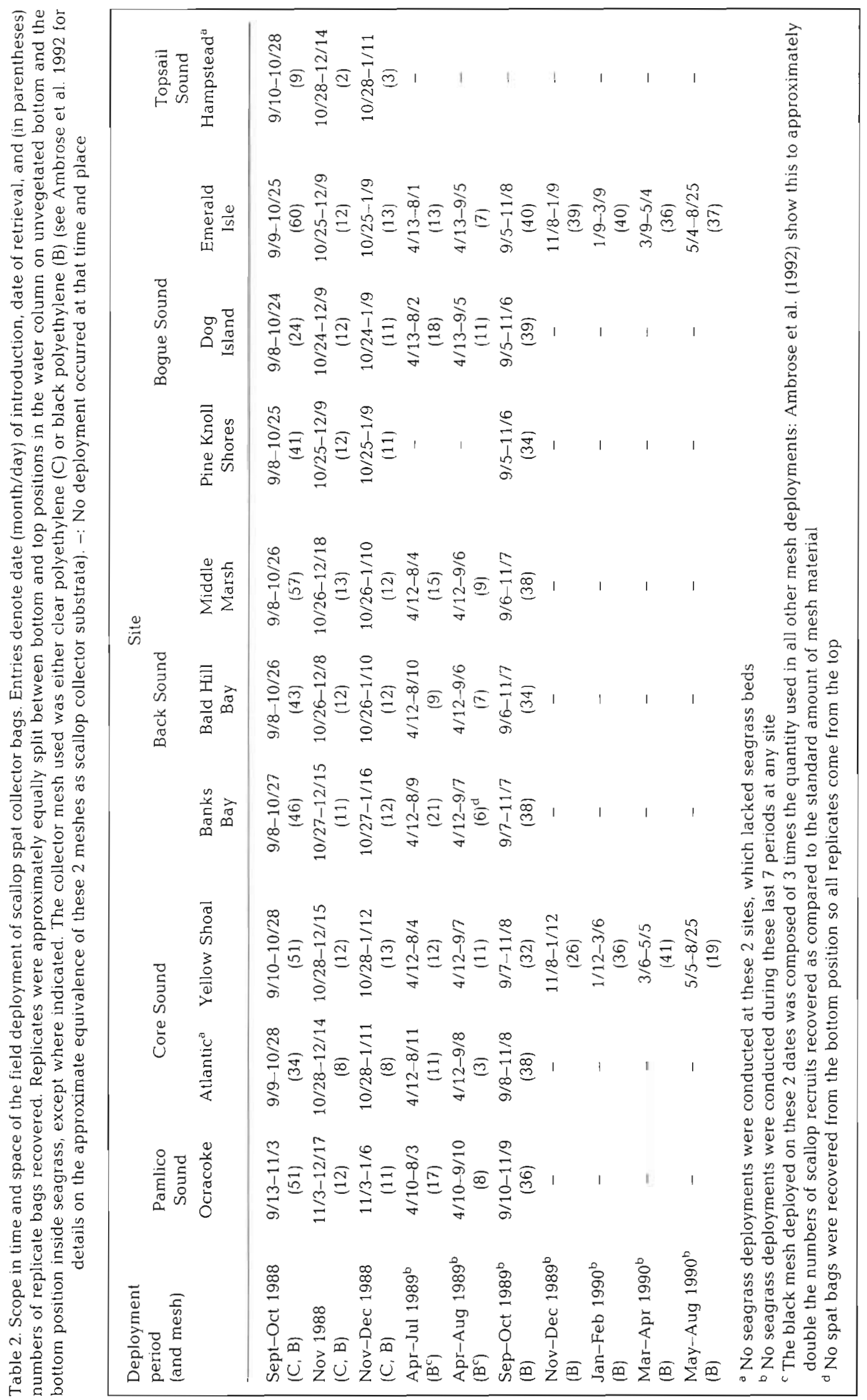


scallop settlement. Our most intense effort was directed towards assessing the spatial pattern of scallop settlement during the primary settlement period in autumn of both 1988 and 1989, by deploying spat collectors at 8 of the same 9 sites where field sampling for adults and recruits was being conducted, plus 1 additional site (Table 2: rows 1 and 6).

In addition, we deployed spat collectors during other seasons of the year at up to 10 sites (Table 2) to test whether the early autumn is indeed the dominant period for bay scallop settlement in North Carolina across all sounds. This spatio-temporal contrast of settlement intensities included sequential deployments of collectors that spanned the full year from September 1989 to August 1990 at 2 sites (Yellow Shoal in Core Sound and Emerald Isle in Bogue Sound; Table 2). By counting the newly settled bay scallops on each collector, we constructed an index of settlement intensity that can be contrasted across sites or times.

The spat collectors were fabricated by enclosing a piece of plastic mesh inside a $5 \mathrm{~mm}$ mesh 'onion bag' that was anchored to the bottom by a rope attached to a cement block and held vertical by an enclosed float. The mesh that was enclosed as a settlement substratum inside the spat collector bags was made identical across sites for each time interval, but varied somewhat among time intervals (Table 2). The mesh type was either a fixed size $\left(0.23 \mathrm{~m}^{2}\right)$ of black $4 \mathrm{~mm}$ polyethylene, a piece of clear $3 \mathrm{~mm}$ polyethylene of the same size, or a piece of the black mesh 3 times as large.

For the first 3 intervals, the settlement bags were deployed in equal numbers in 3 different positions Inear bottom (bottom of bag at $20 \mathrm{~cm}$ ) within seagrass, near bottom (at $20 \mathrm{~cm}$ ) outside seagrass, and near surface (at $120 \mathrm{~cm}$ ) outside seagrass] at all sites except Atlantic and Hampstead, where a lack of seagrass precluded the first position. On all other deployments, settlement bags were equally split between the 2 outsideseagrass positions, eliminating the seagrass position because of its high among-bag variability. To create an index of site-specific settlement intensity for the purposes of this study, we used an unweighted average of the means of all combinations of mesh and position treatments that were deployed at a given site and time period. This is an appropriate index for contrast of sites (Atlantic and Hampstead were not included) within any given time that avoids bias of overweighting by any particular position or mesh treatment. For contrasts over time, deployments including the seagrass position bias this index downwards and deployments using the triple size mesh bias it upwards because of differences in settlement intensity by position and mesh amount (as detailed in Ambrose et al. 1992), but this does not preclude detection of strong temporal patterns in the results below.
Spatio-temporal contrasts of settlement results were used in several ways to enhance our appreciation of the importance of settlement to bay scallop dynamics. First, deployment of collectors included 2 sites that lacked abundant adult scallops, allowing assessment of whether competent scallop larvae were arriving at those sites in lower numbers than at other sites containing adults. Collectors at Atlantic were located approximately 4 to $6 \mathrm{~km}$ from the nearest dense accumulation of adult bay scallops, which existed in the same water body (Core Sound) in the region around Yellow Shoal. Similarly, the Hampstead site in Topsail Sound was located about $40 \mathrm{~km}$ from the nearest accumulation of adult scallops, which existed in a separate water body (western Bogue Sound). Second, data from the 8 other sites used in the fall settlement season deployments were compared to our sampling estimates of adult abundance prior to spawning to address whether variation among sites in settlement intensity could be explained by variation in adult scallop density. Third, these settlement data collected in October were compared to sampling data on average density of recruits in December to test how faithfully among-site patterns of settlement persisted through 2 subsequent months of juvenile life.

Juvenile seeding experiment. As an estimate of juvenile bay scallop survivorship from late winter until the end of autumn, and as one measure of the feasibility of seeding depleted bay scallop grounds with juvenile scallops to enhance subsequent abundance of spawning adults, we conducted an experimental introduction of juvenile bay scallops into each of 2 relatively isolated seagrass beds within the region previously affected by the red tide of 1987-88. Both embayments, one of $5200 \mathrm{~m}^{2}$ in the Middle Marsh complex toward the western end of Back Sound and the other of $6000 \mathrm{~m}^{2}$ in Burden Channel off Emerald Isle near the extreme western end of Bogue Sound (Fig. 1), contained mixed beds of 2 seagrasses, Zostera marina and Halodule wrightii. Water depths ranged from intertidal to about $0.6 \mathrm{~m}$ deep at low tide, averaging around $0.3 \mathrm{~m}$. At the time of introduction, bay scallops were rare in both beds $\left(0.43\right.$ scallops $\mathrm{m}^{-2} \pm 1.24 \mathrm{SD} ; \mathrm{n}=30$ $0.5-\mathrm{m}^{2}$ samples in Middle Marsh and $0.71 \mathrm{~m}^{-2} \pm 1.47$ $\mathrm{SD} ; \mathrm{n}=300.5-\mathrm{m}^{2}$ samples in Burden Channel), but each embayment had a historical record of containing abundant adult bay scallops. Each embayment was isolated from the open sound by shallow shoals, which presumably minimized emigration of the experimental scallops.

The scallops used for this experiment had been collected from our spat collector bags in autumn 1989 and then grown in laboratory upwellers until March 1990. using as the food source unsupplemented raw seawater pumped in from the Intracoastal Waterway in 
Bogue Sound. The average shell heights of the scallops on 29 to 30 March from random subsamples when they were introduced into the field sites were $2.02 \mathrm{~cm}$ ( $\mathrm{SE}=$ $0.02 ; \mathrm{n}=454)$ for Middle Marsh and $2.17 \mathrm{~cm}(\mathrm{SE}=0.03$; $\mathrm{n}=325$ ) for Burden Channel off Emerald Isle. Before introduction into the field sites, the scallops were all marked by spraying a thin layer of red-colored hydraulic cement (Hudson 1972) onto the surface of one valve. Hudson (1972) reports no loss of mark over 15 mo, which is consistent with our experience in which several hundred scallops held in mesh bags in the field retained marks without loss over 4 mo. Scallops were not individually marked because the survivorship estimation did not require it and because they are susceptible to death during handling. As an estimate of handling mortality, a random subset of the juvenile scallops from each site was returned to the laboratory instead of being planted in the field to determine percent mortality from both marking and handling. This procedure overestimates by a factor of 2 handling mortality if mortality rate is proportional to time of transit, but is approximately correct if mortality risk increases with the number of markings and handlings. The rest of the scallops, 7269 at Middle Marsh and 7418 at Burden Channel, were introduced into the field by broadcasting them by hand into subtidal seagrass from a small boat at high tide. Seeded scallops were observed through $3 \mathrm{~h}$ of the falling tide at each site: tidal currents failed to erode and transport any of the seed scallops from the positions where they landed inside each embayment.

The introduced scallops were sampled in late November 1990 (21 to 26 Nov at Burden Channel and 26 to 30 Nov at Middle Marsh) just before the opening of the commercial bay scalloping season in the first week of December. At this time scallops had reached adulthood and could be sampled most efficiently by repeatedly dragging the bottom with a commercial scallop dredge at high tide. Sampling was done at each site by dragging the bottom of the entire embayment systematically and repeatedly over multiple days until a full day of sampling yielded no more scallops. All living, marked scallops that were recovered were measured.

\section{RESULTS}

\section{Bay scallop catch statistics over time}

Commercial catch statistics for bay scallops in North Carolina (Fig. 2) reflect both the magnitude of the direct impact of the 1987-88 red tide event and the absence of recovery in the 3 subsequent year-classes. This toxic dinoflagellate (Ptychodiscus brevis) bloom reduced landings in the $1987-88$ season through direct mortality of adult scallops, and reduced 1988-89 landings through inhibition of successful recruitment of that year-class (Summerson \& Peterson 1990). Fig. 2 demonstrates that commercial landings of bay scallops in the next 3 year-classes, harvested in the 1989-90, 1990-91, and 1991-92 seasons, were still grossly depressed despite normal prosecution of the fishery in those seasons. This depressed abundance is evident in landings from Bogue Sound separately and from Core and Back Sounds combined (Fig. 2). Unfortunately, catch statistics are not kept separately for Core and Back Sounds so the data in Fig. 2 cannot be used to test whether the catch in central Core Sound remained relatively stable from before to after the red tide. The landings over the 1989-90,1990-91, and 1991-92 period, entirely free of any direct effects of the red tide

Fig. 2. Argopecten irradians concentricus. The 27 yr record of commercial harvest of bay scallops in North Carolina (statistics courtesy of the North Carolina Division of Marine Fisheries). Shown separately are the landings from (a) Bogue Sound and (b) Core and Back Sounds combined, where the information is available, and (c) all areas within the state [which includes Pamlico Sound and other smaller water bodies as well as the sum of (a) and (b)). The red tide occurred from October 1987 until February 1988 and directly affected the harvest of the 1987-88 and 1988-89 year-classes. Subsequent 3 year-classes are denoted with * to emphasize the period free from the direct effects of the red tide

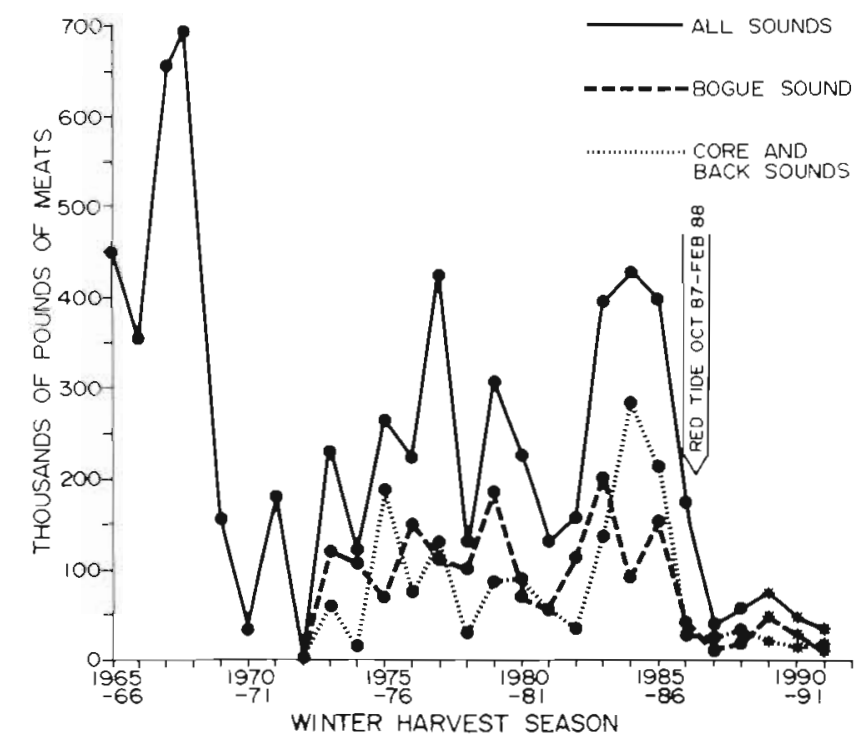




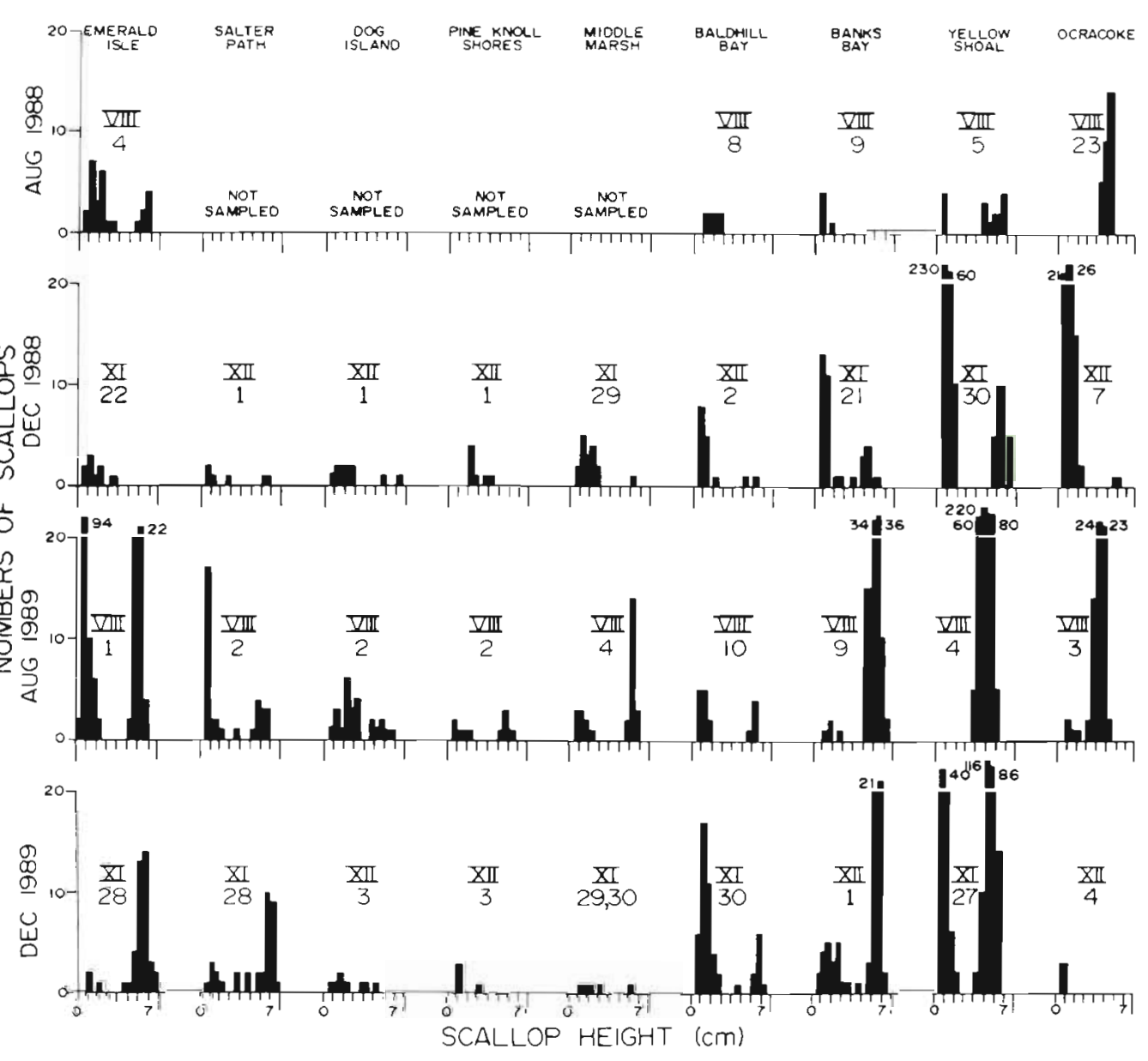

Fig. 3. Argopecten irradians concentricus. Size-frequency distributions of bay scallops at each site in each month of sampling Scallop height was measured on every scallop sampled from umbo to ventral margin. Actual sampling dates are indicated for each histogram with Roman (month) and Arabic (day) numerals. Numbers of replicate $0.5 \mathrm{~m}^{2}$ samples to produce each histogram are provided in Table 1

event, represent a virtual crash in the fishery to levels of 10 to $15 \%$ of historical (1984 to 1986 or 1965 to 1986 ) averages.

\section{Field sampling and settlement on spat collectors}

Size-frequency distributions from the field samplings at 9 seagrass beds demonstrate that in both August and December bay scallop populations are readily subdivided into 2 size classes, one between about 0.5 and $2.5 \mathrm{~cm}$ and another at about 5 to $8 \mathrm{~cm}$ (Fig. 3). This is true at all sites except Ocracoke in Pamlico Sound, where the larger scallops fall generally within a 3 to $6 \mathrm{~cm}$ size, substantially smaller than at the other sites. Nevertheless, using the size of $4 \mathrm{~cm}$ to subdivide the bay scallop population into recruits and adults resulted in a relatively unambiguous distinction at all sites in both months because few scallops occurred in the range of about 2.5 to $4.0 \mathrm{~cm}$ in shell height. This pattern conforms with the observations for previous years in Peterson et al. (1989) and supports our use of $4 \mathrm{~cm}$ as a boundary to separate recruits from adult scallops.

In 1988, the pattern of abundances of adults among sampling sites was a good predictor of the pattern of settlement and recruitment (Fig. 4). Using the average densities of adults at all 9 sites in the December sampling as an indication of what the pattern of adult densities had been at the time of spawning 2 to 3 mo earlier, knowledge of the adult density in December at each of the 9 sites explained $81 \%$ of the variance among sites in the October settlement data and $80 \%$ of the variance among sites in the December recruitment data in linear regressions (Fig. 4). Settlement pattern among sites explained $71 \%$ of the variance in recruitment 2 mo later in the 1988 data. Sampling of adults in August 1988 did not cover enough of the 9 sites to make those data useful in the analysis of effects of adult distribution pattern on settlement and recruitment. 
In 1989, the fits among data sets were again strong except for contrasts involving the settlement data. The August sampling of adults in 1989 did take place at all 9 sites and demonstrated that the pattern of adult densities in August of 1989 explained $96 \%$ of the variance among sites in densities of adult scallops in December (Fig. 4). This result helps support our use of December adult data in 1988 as proxy for the uncollected August 1988 adult information. In analysis of the 1989 sampling results, using either August or December adult densities as an indicator of the pattern of abundance of spawners in the late August-late October period, adult densities explained a significant 65 to $71 \%$ of the variance in December recruitment among sites (Fig. 4). However, in 1989 the data recorded from the settlement bags did not match the pattern of adult abundances in August or December or the pattern of abundances of recruits in December. The deviations in the settlement data came from anomalously high settlement at 2 sites, Middle Marsh and Emerald Isle (Fig. 4). For these sites in 1989, post-settlement mortality presumably played a role in setting recruitment intensity, unless settlement bags give a non-representative indication of settlement to the natural substrata, seagrass blades.

The patterns among sites of settlement and recruitment in 1988 were well reflected in the distributions of abundance of adult scallops in both August and December 1989. The pattern of settlement among sites evident in the October 1988 settlement bags explained $90 \%$ of the variance in adult bay scallop abundance among sites in the following autumn (Fig. 4). Similarly, the pattern exhibited in the 1988 December recruit data explained 88 to $93 \%$ of the variance among sites in adult abundances in August and December 1989 (Fig. 4). No data are available to perform this same analysis on how faithfully the autumn 1989 settlement or recruitment pattern may have been perpetuated into 1990 adult distributions.

Comparisons of the December sampling data from 1988 and 1989 to identically collected data on densities
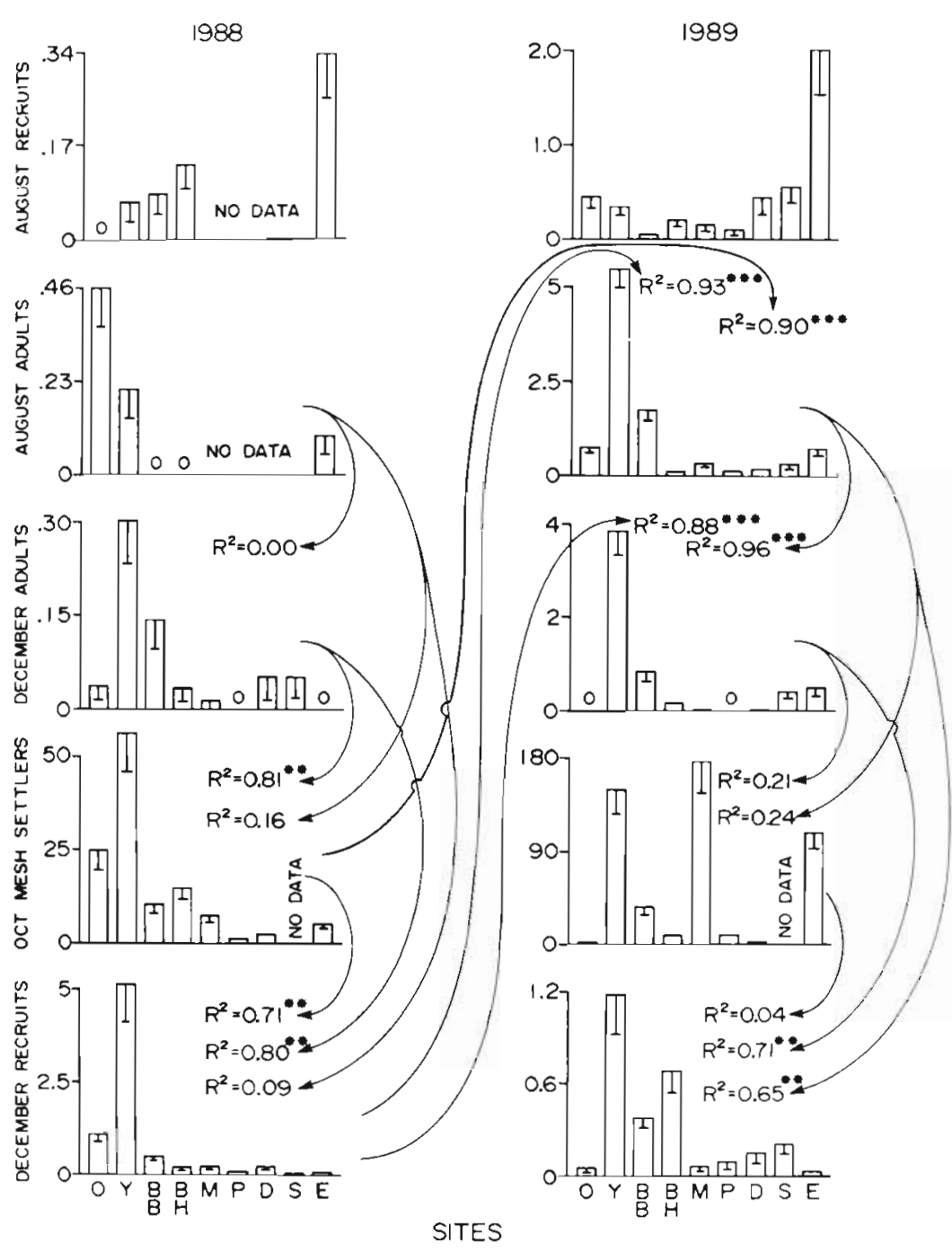

Fig. 4. Argopecten irradians concentricus. Average densities (-SE) per $0.5 \mathrm{~m}^{2}$ of adult ( $>4 \mathrm{~cm}$ shell height) and recruit $(<4 \mathrm{~cm}$ ) bay scallops from August and December samplings in each of 2 years, as well as average numbers of settlers $(-\mathrm{SE})$ per spat collector bag collected in October of each year. Letters indicate sampling sites, shown in Fig. 1. Sample sizes and dates appear in Table $1 . \mathrm{R}^{2}$-values represent the proportion of variance explained in linear regressions between data sets as indicated by the arrows: ${ }^{\circ} p<0.05 ; \cdots p<0.01 ; \cdots p<0.001$; no symbol: $p>0.05$. Settlement results for Atlantic (which lacked seagrass and scallops and therefore was not included in the sampling program) were: 3.3 (SE 0.90) scallops per settlement bag in October 1988 and 1.7 (SE 0.31) in October 1989

of both recruits and adult bay scallops in December during years immediately prior to the red tide event demonstrates a geographic pattern of persisting differences that continues to match the immediate post-redtide pattern. Compared to the years just before 1987 , the average densities of recruits in 1988-89 were virtually unchanged at Yellow Shoal in the middle of Core Sound, while the 2 Back Sound sites sampled both before and after the red tide exhibited recruit densities in 1988-89 that were only $29 \%$ of what might be expected from the previous recruitment data 
Table 3. Argopecten irradians concentricus. Densites per $0.5 \mathrm{~m}^{2}$ of bay scallop recruits and adults in December of 1988 and 1989 as compared to historical mean. December densities for 3 yr just before the 1987-88 red tide (data from Summerson \& Peterson 1990). -: No data available

\begin{tabular}{|c|c|c|c|c|c|c|c|c|}
\hline \multirow[t]{2}{*}{ Sound and seagrass bed ${ }^{a}$} & \multicolumn{4}{|c|}{ Recruits } & \multicolumn{4}{|c|}{ Adults } \\
\hline & $\begin{array}{l}\text { Historical } \\
\text { mean }\end{array}$ & $\begin{array}{l}\% \text { in } \\
1988\end{array}$ & $\begin{array}{l}\% \text { in } \\
1989\end{array}$ & $\begin{array}{l}\text { Soundwide } \\
\text { average } \%\end{array}$ & $\begin{array}{l}\text { Historical } \\
\text { mean }\end{array}$ & $\begin{array}{l}\% \text { in } \\
1988\end{array}$ & $\begin{array}{l}\% \text { in } \\
1989\end{array}$ & $\begin{array}{l}\text { Soundwide } \\
\text { average } \%\end{array}$ \\
\hline \multicolumn{9}{|l|}{ Pamlico Sound } \\
\hline Ocracoke & - & -- & - & - & - & - & - & - \\
\hline \multicolumn{9}{|l|}{ Core Sound } \\
\hline Yellow Shoal ${ }^{3}$ & 3.05 & 170 & 38 & 104 & 0.63 & 47 & 606 & 326 \\
\hline \multicolumn{9}{|l|}{ Back Sound } \\
\hline Banks Bay ${ }^{2}$ & 1.24 & 39 & 30 & & 1.12 & 13 & 74 & \\
\hline Bald Hill Bay ${ }^{3}$ & 1.95 & 13 & 35 & 29 & 0.28 & 13 & 60 & 40 \\
\hline Middle Marsh & - & - & - & & - & - & -1 & \\
\hline \multicolumn{9}{|l|}{ Bogue Sound } \\
\hline Pine Knoll Shores & - & - & - & & - & - & - & \\
\hline Dog Island & - & - & - & 5 & - & - & - & 50 \\
\hline Salter Path ${ }^{1}$ & 3.03 & 3 & 7 & 5 & 0.37 & 14 & 157 & 50 \\
\hline Emerald Isle $^{3}$ & 2.28 & 7 & 2 & & 2.01 & 0 & 31 & \\
\hline
\end{tabular}

and the 2 Bogue Sound sites only $5 \%$ of their previous levels of recruitment (Table 3). Adult densities in December reflected similar patterns with the Core Sound site demonstrating average densities over 1988-89 that far exceeded the 3 yr average from before the red tide, whereas the average December densities of adults in both Back Sound and Bogue Sound were only 40 to $50 \%$ of their previous 3 yr mean levels (Table 3). The 1989-90 year-class (those scallops fished in 1989-90) was generally much stronger than the 1988-89 year-class (evident in Figs. 4 \& 2), but the relative differences among sounds existed in both years (Table 3 ).

Comparisons between August and December in the intensity of settlement onto spat collectors and in recruit densities shed light on the accuracy of the presently accepted life-history model for bay scallops in North Carolina waters. August and December recruitment data should be comparable because each estimate recruitment at about the same time after settlement, 2 to 3 mo since the late spring and late summer settlement periods respectively (Gutsell 1930, Sastry 1966). Numbers of scallop settlers recovered from the settlement bags (Table 4) reveal a strong seasonality, with numbers in the September-October deployments of both years far higher than during any other time period at almost all sites. The deployments that included the expected secondary settlement period during May also exhibited some settlement, but far less than the fall settlement at virtually all sites (Table 4). The site in Atlantic at 4 to $6 \mathrm{~km}$ distance from accumulations of adult scallops did receive settlers, but fewer and later than at Yellow Shoal, also in Core Sound. The deployment at Hampstead outside the range of commercially harvestable densities of bay scallops demonstrated negligible settlement.

Sampling of recruits about 2 to 3 mo after the 2 settlement periods provides insight into which settlement period contributes most to population maintenance. In 1988, the August recruitment from field sampling was a small fraction of the December recruitment, less than $15 \%$ at all sites except Bald Hill Bay and Emerald Isle, where no significant difference could be detected (Table 5). During August of 1988, however, only 5 sites were sampled and of those only 1 was located in Bogue Sound. In 1989, when all 9 sites were sampled, Emerald Isle exhibited far greater recruitment in August than in December, as did Ocracoke, while the two sites in Core Sound (Yellow Shoal and Banks Bay) and Bald Hill Bay in Back Sound revealed greater December recruitment (Table 5). None of the sites from western Back Sound to central Bogue Sound demonstrated detectable differences in recruitment between the spring and fall seasons.

\section{Juvenile seeding experiment}

Recovery rate of adult bay scallops that had been introduced into 2 field sites as juvenile recruits 8 mo earlier was low and did not differ greatly from site to site (Table 6). Using an observed $11.5 \%$ (Middle Marsh) and $10.7 \%$ (Burden Channel) mortality from handling during marking and introduction to correct the initial numbers for handling mortality, the 36 scallops recovered at Middle Marsh represent $0.55 \%$ of 


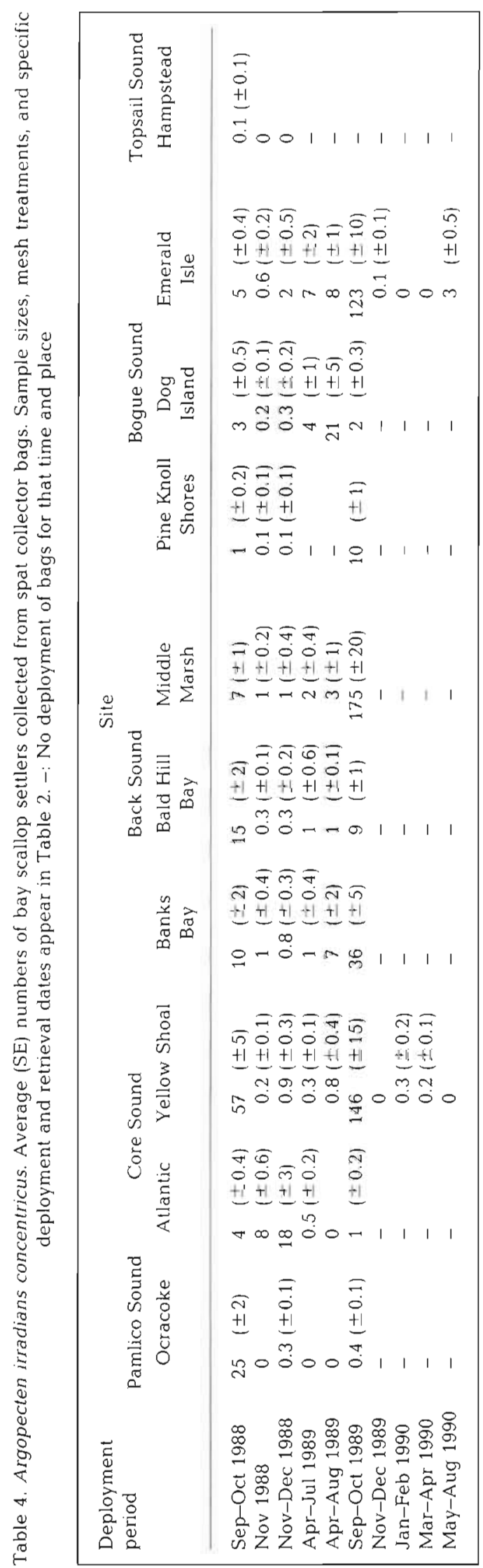

the 6433 estimated living introductions, compared to $1.62 \%$ recovered as living adults at Burden Channel out of an estimated 6623 living juvenile introductions (Table 6). These recovery estimates may be biased upwards by the use of estimates of handling mortality that include a round trip in the boat and biased downwards by any failure to recapture all live scallops and by any emigration of live scallops out of the embayments. There was little variation in shell heights among the scallops at recovery, with mean sizes of 6.36 and $5.91 \mathrm{~cm}$ at the 2 sites well within the normal adult size range for this date and region (Fig. 3 and Peterson et al. 1989).

\section{DISCUSSION}

Although the red tide of October 1987 through February 1988 could not have had any direct effect on the 1989-90,1990-91, and 1991-92 year-classes of the bay scallop, the ghost of the red tide is still evident in the extremely low landings of these 3 subsequent yearclasses (Fig. 2). The landings in 1989-90, 1990-91, and 1991-92 are lower than bay scallop landings in any of the 23 year-classes immediately preceeding the red tide except those during 1970-71 and 1972-73, and these recent lows are only about 10 to $15 \%$ of the 1984-86 and 1965-86 landings. Even if neither 1984-86 nor 1965-86 were chosen as a standard against which to compare the period after the red tide, it is still evident that the crash in the fishery is quite dramatic (Fig. 2). This failure of the stock to recover rapidly repeats the history of recovery from the population decline from undetermined causes in 1970-73: it took 5 to $12 \mathrm{yr}$ for the bay scallop landings to exhibit an erratic return to the levels characteristic of the mid 1960 's and they never again have reached the high levels of 1968-69 (Fig. 2). We suggest these 5 to $12 \mathrm{yr}$ recovery times because regression analyses from the low point of $1972-73$ to the relative high point $5 \mathrm{yr}$ later and to that $12 \mathrm{yr}$ later both represent significant temporal trends $\left(\mathrm{r}^{2}=0.71: \mathrm{p}=0.03\right.$ and $\mathrm{r}^{2}=0.32: \mathrm{p}=$ 0.03 , respectively). If the regressions are instead calculated starting from $1970-71$ as the low, the trends are again significant at even lower $p$-values $(p=0.02$ and $p=0.008)$. We recognize the ad hoc nature of these calculations and realize that they are driven largely by the endpoints, which we selected. Nevertheless, they do suggest a time scale for recovery.

Because the bay scallop fishery begins in December and continues into the spring each year until scallop densities have reached levels below those that make fishing economically viable, these temporal landings patterns are a reasonable reflection of actual adult population fluctuations. Our quantitative sampling of bay scallop abundances before opening of the scallop- 
Table 5. Argopecten irradians concentricus. Differences in densities (per $\left.0.5 \mathrm{~m}^{2}\right)$ of bay scallop recruits ( $<4 \mathrm{~cm}$ in shell height) in August vs December at several sites in each of 2 yr. Standard errors around the means are given in parentheses. -: No data taken. Sample sizes can be obtained from Table 1. Superscript symbols indicate significance in t-tests for unequal variances performed to compare August and December recruit densities: ${ }^{\cdot p} p<0.05 ;{ }^{\prime} p<0.01_{i} \cdots p<0.001$

\begin{tabular}{|c|c|c|c|c|c|c|}
\hline \multirow[t]{2}{*}{ Site $^{a}$} & \multicolumn{3}{|c|}{1988} & \multicolumn{3}{|c|}{1989} \\
\hline & August (A) & December (D) & $A-D$ & August $(A)$ & December (D) & $A-D$ \\
\hline Ocracoke & $\begin{array}{c}0.00 \\
(0.00)\end{array}$ & $\begin{array}{c}1.07 \\
(0.21)\end{array}$ & $-1.07 \cdots$ & $\begin{array}{c}0.46 \\
(0.09)\end{array}$ & $\begin{array}{c}0.05 \\
(0.04)\end{array}$ & $0.41 \cdots$ \\
\hline Yellow Shoal & $\begin{array}{c}0.07 \\
(0.03)\end{array}$ & $\begin{array}{c}5.18 \\
(0.92)\end{array}$ & $-5.11 \cdots$ & $\begin{array}{c}0.33 \\
(0.08)\end{array}$ & $\begin{array}{c}1.16 \\
(0.23)\end{array}$ & $-0.83 \cdots$ \\
\hline Banks Bay & $\begin{array}{c}0.08 \\
(0.03)\end{array}$ & $\begin{array}{c}0.48 \\
(0.13)\end{array}$ & $-0.40^{\cdots}$ & $\begin{array}{c}0.07 \\
(0.03)\end{array}$ & $\begin{array}{c}0.37 \\
(0.08)\end{array}$ & $-0.30 \cdots$ \\
\hline Bald Hill Bay & $\begin{array}{c}0.14 \\
(0.04)\end{array}$ & $\begin{array}{c}0.25 \\
(0.09)\end{array}$ & -0.11 & $\begin{array}{c}0.20 \\
(0.07)\end{array}$ & $\begin{array}{c}0.68 \\
(0.14)\end{array}$ & $-0.48^{\cdots}$ \\
\hline Middle Marsh & - & $\begin{array}{c}0.28 \\
(0.08)\end{array}$ & - & $\begin{array}{c}0.16 \\
(0.07)\end{array}$ & $\begin{array}{c}0.07 \\
(0.03)\end{array}$ & 0.09 \\
\hline Pine Knoll Shores & - & $\begin{array}{c}0.18 \\
(0.07)\end{array}$ & - & $\begin{array}{c}0.12 \\
(0.05)\end{array}$ & $\begin{array}{c}0.11 \\
(0.06)\end{array}$ & 0.02 \\
\hline Dog Island & - & $\begin{array}{c}0.26 \\
(0.12)\end{array}$ & - & $\begin{array}{c}0.46 \\
(0.18)\end{array}$ & $\begin{array}{c}0.15 \\
(0.06)\end{array}$ & 0.31 \\
\hline Salter Path & - & $\begin{array}{c}0.10 \\
(0.06)\end{array}$ & - & $\begin{array}{c}0.56 \\
(0.18)\end{array}$ & $\begin{array}{c}0.21 \\
(0.07)\end{array}$ & 0.35 \\
\hline Emerald Isle & $\begin{array}{c}0.34 \\
(0.08)\end{array}$ & $\begin{array}{c}0.17 \\
(0.05)\end{array}$ & 0.17 & $\begin{array}{c}1.98 \\
(0.46)\end{array}$ & $\begin{array}{c}0.05 \\
(0.04)\end{array}$ & $1.93^{*} \cdots$ \\
\hline
\end{tabular}

ing season in December in each of several years before and after the red tide event confirm the persistence of relatively low population abundances (Table 3), especially in Bogue and Back Sounds where most of the population has historically been located (Summerson \& Peterson 1990).

Although there is clearly large year-to-year variability in the year-class strength of bay scallops (as is typical of scallops: see Dickie 1955, Wolff 1988), the pattern of slow recovery from low levels of abundance is nonetheless evident (Fig. 2). Recovery of the bay scal- lop from brown tide losses in Long Island has also been a slow process (Tettelbach \& Wenczel 1991). This type of population response implies (although does not convincingly show) that at low population sizes recruitment may limit population size in this species because of spawning limitation (e.g. Sutherland 1987, Hughes 1990, Karlson \& Levitan 1990). As spawning stock approaches zero, this is necessarily true for any population. However, the gradual but erratic recovery of the bay scallop population from the low levels of the early 1970's (Fig. 2) also suggests that recruitment limitation

Table 6. Argopecten irradians concentricus. Recovery as adults in November (21 to 30 Nov 1990) of bay scallops introduced in March (29 to 30 March 1990) as marked juveniles (2.02 to $2.17 \mathrm{~cm}$ in shell height) at each of 2 sites

\begin{tabular}{|c|c|c|}
\hline \multirow[t]{2}{*}{ Parameter } & \multicolumn{2}{|c|}{ Site } \\
\hline & Middle Marsh & Burden Channel \\
\hline Total no. introduced as juveniles & 7269 & 7418 \\
\hline Estimated no. introduced alivea & 6433 & 6623 \\
\hline Total no. recovered alive as adults & 36 & 107 \\
\hline Percentage live recovery & $0.55 \%$ & $1.62 \%$ \\
\hline Mean shell height (in $\mathrm{cm}$ ) of recovered marked scallops (SE) & $6.36(0.05)$ & $5.91(0.03)$ \\
\hline \multicolumn{3}{|c|}{$\begin{array}{l}\text { This estimate represents a reduction from the total number introduced to account for estimated handling mortality. Handling } \\
\text { mortality was estimated by marking and handling a subset of juvenile scallops in identical ways to those that were introduced } \\
\text { but instead of releasing them returning them to the laboratory to assess mortality. Of } 454 \text { returned to the laboratory from } \\
\text { Middle Marsh, } 59 \text { or } 11.5 \% \text { died within } 24 \mathrm{~h} \text {; of } 325 \text { returned from Burden Channel, } 39 \text { or } 10.7 \% \text { died. If handling mortality } \\
\text { increases linearly with holding time, then the procedure used here overestimates handling mortality by a factor of } 2\end{array}$} \\
\hline
\end{tabular}


may exist in bay scallops from 2 sources. First, there is clearly a high degree of year-to-year variability, which may be in large measure a consequence of variable larval mortality limiting recruitment (as suggested by Dickie 1955 and Wolff 1988 for other scallops). But in addition, the significant temporal increase over either a 5 yr or a 12 yr period after the low in 1970-71 sug. gests that at depressed densities a positive stockrecruitment relationship may also be superimposed upon the noise. This suggestion gains support from the current post-red-tide observations, showing no initiation of recovery from depressed population levels (Fig. 2 ). This suggestion conflicts with the usual assumption applied in management of virtually all invertebrate fisheries that fecundity is so high that over a wide range of adult densities there is no effective spawnerrecruit relationship (Hancock 1973).

Our 2 yr of data on bay scallop settlement and recruitment as a function of adult abundance in each water body (Fig. 4, Table 3) support the characterization of the bay scallop as a recruitment-limited population. The recruitment limitation appears to operate within water bodies: central Core Sound did not suffer any direct mortality from the red tide (Summerson \& Peterson 1990) and both adult scallop abundance and settlement and recruitment continue to be high relative to the other water bodies. Bogue Sound suffered almost complete recruitment failure in December 1987 from the red tide (Summerson \& Peterson 1990) and neither the adult spawner population nor the settlement and recruitment has yet recovered. The Back Sound sites geographically between the other 2 sounds tend to have somewhat higher densites of adult bay scallops than Bogue Sound sites and also somewhat higher levels of scallop settlement and recruitment.

For the brief $2 \mathrm{yr}$ period of our study, the pattern of adult bay scallop abundances among the study sites, separated by a few kilometers and partially isolated further by locations in separate but connected water bodies (Fig. 1), tends to be perpetuated through subsequent settlement, recruitment, and adult life stages (Fig. 4). This pattern differs radically from the historical pattern of abundances among sites, particularly in that the Bogue Sound sites consistently held the most dense bay scallop populations before the red tide (e.g. Table 3). Consequently, localized dynamics and spawner-recruit relationships within sounds may be contributing importantly to coherence of population dynamics among sites and sounds. It is interesting to note in this context that Hampstead in Topsail Sound, a water body in which bay scallop abundance is too low to support commercial harvest and which possesses only an indirect ocean connection with Bogue Sound where high densities of bay scallops normally occur, experienced negligible bay scallop settlement. This and our other settlement and recruitment data suggest a scale of larval dispersal for the bay scallop consistent with a short larval life-span and with estuarine retention of larvae. Subsequent larval investigations are needed, however, to test this implication.

Because our suggestion that the bay scallop in North Carolina may represent a collection of recruitmentlimited subpopulations on a scale of water basins is derived from inferring process in observational data on spatio-temporal dynamics rather than from direct experimental test, it is important to address potential alternative explanations. It is possible that the habitat for bay scallops in North Carolina changed in a pattern coincident in time and space with the population reductions caused by the red tide. In other words, between the 1984-86 period and the 1989-92 post red-tide period, important aspects of bay scallop habitat may have deteriorated dramatically in Bogue Sound, declined greatly but not quite as much in Back Sound, and remained stable in Core Sound. Some data are available to address this possibility for perhaps the single most important aspect of bay scallop habitat that is likely to vary on this time scale, the extent of seagrass cover. Ferguson et al. (1992) report results of digitizing seagrass cover from aerial photography of the full extents of Core Sound and Back Sound in both 1985 and 1988, spanning the red-tide incident. The estimated areal coverage of seagrass beds in eastern Core Sound where our scallop grounds occur changed from 4998 to 4718 ha, a $6 \%$ loss, while coverage in Back Sound changed from 1311 to 1075 ha, an $18 \%$ loss. This difference in percentage decline of seagrass habitat between the 2 sounds is in the right direction but, assuming an approximately linear relationship, is of insufficient magnitude to explain the large drop in bay scallop production in Back Sound from the pre- to the post-red-tide period. Unfortunately, analogous data from Bogue Sound, where the largest declines in scallop populations occurred, are not yet available.

Another alternative explanation for the pattern of slow recovery of bay scallops after the red tide relates to sources of either larval or post-settlement mortality. The large declines in relative abundance at both Middle Marsh and Emerald Isle in 1989 from the settlement stage to the recruitment stage (Fig. 4) suggest that post-settlement mortality can at least occasionally play a role in setting spatial pattern of abundance in bay scallops. The commonly observed (see Dickie 1955 and Wolff 1988 for a discussion) high temporal variability of abundance of scallop populations is usually interpreted to imply great variation in larval mortality from predation or advection. It is possible that important sources of post-settlement mortality have increased in Bogue Sound and to a lesser degree in Back Sound relative to Core Sound after the red tide inci- 
dent. However, this explanation conflicts with most of our results showing that adult abundance among sites could be explained by earlier settlement and recruitment patterns. Furthermore, there is no obvious reason to expect larval or post-settlement mortality rates to have changed and persisted among sounds in a fashion coincident in time and space with the red tide outbreak.

Our data on the bay scallop in North Carolina do not speak to the question of how recruitment limitation at low density might exist despite the presence of not insignificant numbers of adult scallops. Even after the red tide reduced bay scallop abundances so dramatically in Bogue and Back Sounds, the total numbers of adult bay scallops present at the spawning seasons must be quite large when pooled over the entire expanse of habitat. Why these adults cannot readily repopulate the 2 sounds, given their fecundity (Sastry 1963, 1966), is not obvious. Many causes of mortality for the planktonic larval stages exist that may help explain continued low recruitment. Post-settlement mortality could be an additional contributor: even the scallops in settlement bags represent individuals surviving for several weeks after actual settlement. In addition, however, there are recent compelling data for an echinoderm that demonstrate that for marine invertebrates with external fertilization small distances on the order of a meter or less are sufficient to dilute sperm concentrations enough to cause huge declines in the percentage of eggs that become fertilized (Levitan et al. 1992). Because bay scallops apparently do not self-fertilize in nature (Sastry 1963. Castagna 1975), this process may contribute to the slow recovery of bay scallop populations and deserves careful consideration.

The possible inclusion of the bay scallop on the list of marine animals for which some evidence of recruitment limitation exists may represent the first species from a soft-bottom habitat. Previous evidence implying possible recruitment limitation comes from reef fishes (Doherty 1983, Warner \& Chesson 1985, Victor 1986. Shulman \& Ogden 1987, Doherty \& Williams 1988) and sea urchins (Karlson \& Levitan 1990), or from invertebrates that attach to hard substrata (Gaines \& Roughgarden 1985, Sutherland 1987, Sammarco \& Andrews 1989, Hughes 1990). Although the bay scallop lives in soft-bottom environments, it lives on rather than within the sediments and is thus unlikely to serve as a representative species in any sense. Nevertheless, the ineffectiveness of competition for resources to induce mortality and thereby regulate populations of marine invertebrates that inhabit soft-sediment systems (Peterson 1979, 1991, Wilson 1991) implies that recruitment to soft-sediment systems may be a generally significant determinant of patterns of population abundance in this environment. A long history of intense study of larval recruitment processes in softsediment systems tends to support this suggestion that variation in time and space of larval settlement is the major contributor to community structure (e.g. Thorson 1950, Woodin 1976, Butman 1987, Eckman 1987).

If bay scallop populations are limited by the abundance of recruits and recruit abundance varies on a basin scale with the density of spawning adult scallops, at least at low population sizes, then management intervention should be considered to speed the otherwise slow recovery of bay scallops from the lingering effects of the red tide in North Carolina. The goal of management intervention should presumably be the enhancement of spawning adults in those areas where populations remain depressed (see Tettelbach \& Wenczel 1991, but also Wolff 1988), especially in the western end and middle of Bogue Sound. Our data showing that a spring settlement produces some appreciable contribution to recruitment in that region (Table 5) imply that managers might consider closing the entire fishing season for bay scallops during an upcoming year so as to enhance the numbers of adult bay scallops surviving the winter to reproduce again in spring and to eliminate possible mortalities of new recruits associated with the bottom-disturbing process of scallop dredging. Another option may be to transplant adult scallops into western Bogue Sound long enough in advance of the spawning season to avoid induction of spawning and to avoid delay of spawning through stress. Such an action could be taken in a way that insures close proximity of spawners so as to avoid any possible distance barrier to fertilization success. This action carries the negative effects of removal of spawners from the donor site, which would not only reduce the numbers of adults available there for harvest beginning in December of that year but also could diminish the numbers of recruits to the subsequent year-classes in that locality. Our data and past experience suggest that this problem could be circumvented by judicious choice of donor sites. In particular, Middle Marsh often receives excellent settlement and recruitment of bay scallops, a large fraction of which oftens survives into September but almost none of which survives until the opening of fishing season in December (Fig. 4 and pers, obs.). Removal of adult scallops from this site during summer would not jeopardize local harvest at that site and thus not carry the costs associated with use of most other donor sites.

A final alternative means of enhancing bay scallop recruitment to the western end of Bogue Sound would be to seed appropriate seagrass beds in that region with small hatchery-reared scallops or scallops collected by use of spat collectors such as the ones that we designed (Ambrose et al. 1992). Our data on the recovery of seed scallops at 2 sites imply relatively low sur- 
vivorship from this introduction, but with enough seed deployed or with different methods those numbers could clearly be enhanced in this fashion. Alternatively, if emigration were substantial survivorship may have been grossly underestimated by our in situ sampling. Even though recovery rates of only about $1 \%$ from introduction of juveniles may not in themselves provide economic justification for bay scallop seeding for the purposes of enhancing that particular year-class, the survivors of our introductions clearly grew to reach normal adult sizes and therefore are likely to have spawned normally (as shown to be important in transplants conducted in Long Island by Krause 1992). Consequently, the seeding of scallops may represent a bioeconomically viable method of enhancing future stock size in depleted areas for scallops if they are recruitment-limited in their basin-wide dynamics. The enhancement of the catch from the direct harvest of introduced scallops may represent only a small fraction of the benefit to the scallop population in a depleted basin where recruitment enhancement is needed. Seeding was successful in stimulating enhanced bay scallop production in Long Island (NY, USA) after extensive brown tide mortality (Tettelbach \& Wenczel 1991).

Although this discussion of management options is focussed on the specific case of the bay scallop fishery in North Carolina, the isssues addressed are generic to an exploited population that is experiencing recruitment limitation because of an effective stock-recruitment relationship. The usual assumption applied to shellfisheries management that fishing pressure on adults will not appreciably diminish recruitment of the subsequent year-class cannot then be justified. Under those circumstances, the issue of how to maximize recruitment is germane and general. Then fishery managers must apply knowledge of ecological processes and often use ecological field experimentation as tools to intervene in the natural ecosystem to promote the sustainability of production of its exploited populations.

Acknowledgements. We thank J. Cahalan, J. Lin, E. B. Olafsson, R. C. Prescott, J. Purifoy, G. Safrit, and F. Wilson for field and laboratory assistance. W. G. Ambrose, Jr, E. A. Irlandi, G. A. Skilleter and 2 anonymous reviewers helped improve the manuscript. Financial support for this project was provided by the EPA Estuaries Program through the Albemarle/Pamlico Estuaries Program, the North Carolina Legislature through the North Carolina Sea Grant College Program, and the University of North Carolina's Institute of Marine Sciences.

\section{LITERATURE CITED}

Ambrose, W. G. Jr, Peterson, C. H., Summerson, H. C., Lin, J. (1992). Experimental tests of factors affecting recruitment of bay scallops (Argopecten irradians) to spat collectors. Aquaculture 108: $67-86$

Belding, D. L. (1910). A report upon the scallop fishery of Massachusetts. Commonwealth of Massachusetts, Boston

Butman, C. A. (1987). Larval settlement of soft-sediment invertebrates: the spatial scales of patterns explained by active habitat selection and the emerging role of hydrodynamic processes. Oceanogr. mar. Biol. A. Rev. 25: $113-165$

Castagna, M. (1975). Culture of the bay scallop. Argopecten irradians, in Virginia. Mar. Fish. Rev. 37: 19-24

Castagna, M., Duggan, W. (1971). Rearing the bay scallop Argopecten irradians. Proc. natl Shellfish Ass. 61.80-85

Dickie, L. (1955). Fluctuations in abundance of the giant scallop, Placopecten magellanicus (Gmelin) in the Digby Area of the Bay of Fundy. Bull. Fish. Res. Bd Can. 12: $787-856$

Doherty, P. J. (1983). Tropical territorial damselfish: is density limited by aggression or recruitment? Ecology 64: 176-190

Doherty, P. J., Williams, D. McB. (1988). The replenishment of coral reef fish populations. Oceanogr. mar. Biol. A. Rev. 26: $487-551$

Eckman, J. E. (1987). The role of eelgrass hydrodynamics in recruitment, growth and survival of Argopecten irradians (L.) and Anomia simplex (D'Orbigny). J. exp. mar. Biol. Ecol. 106: 165-191

Ferguson, R. L., Wood, L. L., Pawlak, B. T (1992). SAV habitat in 1985 and 1988: Cape Lookout to Drum Inlet, North Carolina. NOAA Coastal Ocean Program, Submerged Aquatic Vegetation Study, Beaufort Laboratory, SEFSC, Beaufort, NC

Gaines, S., Roughgarden, J. (1985). Larval settlement rate: a leading determinant of structure in an ecological community of the marine intertidal zone. Proc. natl Acad. Sci. U.S.A. 82: $3707-3711$

Granmo, A., Havenhand, J., Magnusson, K., Svane, I. (1988). Effects of the planktonic flagellate Chrysochromulina polylepis Manton et Park on fertilization and early development of the ascidian Ciona intestinalis (L.) and the blue mussel Mytilus edulis L. J. exp. mar. Biol. Ecol. 124: 65-71

Gutsell, J. S. (1930). Natural history of the bay scallop. Bull. U.S. Bur. Fish. 46: 569-632

Hancock, D. A. (1973). The relationship between stock and recruitment in exploited invertebrates. Rapp. P.-v. Réun. Cons. int. Explor. Mer 164: 113-131

Hudson, J. H. (1972). Marking scallops with a quick-setting cement. Proc. natl Shellfish Ass. 62: 59-61

Hughes, T. P. (1990). Recruitment limitation, mortality, and population regulation in open systems: a case study. Ecology 71: 12-20

Karlson, R. H., Levitan, D. R. (1990). Recruitment limitation in open populations of Diadema antillarum: an evaluation Oecologia 82: $40-44$

Kellogg, R., Spitsbergen, D. (1983). Predictive growth model for the meat weight (adductor muscle) of bay scallops in North Carolina. UNC Sea Grant Publ., UNC-SG-WP-83-6, Raleigh, NC

Krause, M. K. (1992). Use of genetic markers to evaluate the success of transplanted bay scallops. J. Shellfish Res. 11: 199

Levitan, D. R., Sewell, M. A., Chia, F. (1992). How distribution and abundance influence fertilization success in the sea urchin Strongylocentrotus franciscanus. Ecology 73: $248-254$

Orensanz, J. M. (1986). Size, environment, and density: the regulation of a scallop stock and its management implications. Can. Spec. Publ. Fish. Aquat. Sci. 92: 195-227 
Peterson, C. H. (1979). Predation, competitive exclusion, and diversity in the soft-sediment benthic communities of estuaries and lagoons. In: Livingston, R. J. (ed.) Ecological processes in coastal and marine systems. Plenum Press, New York, p. 233-264

Peterson, C. H. (1990). On the role of ecological experimentation in resource management: managing fisheries through mechanistic understanding of predator feeding behaviour. In: Hughes, R. N. (ed.) Behavioural mechanisms of food selection. Springer-Verlag, Berlin. p. $821-846$

Peterson, C. H. (1991). Intertidal zonation of marine invertebrates in sand and mud. Am. Sci. 78: 236-249

Peterson, C. H., Summerson, H. C., Fegley, S. R., Prescott, R. C. (1989). Timing, intensity and sources of autumn mortality of adult bay scallops Argopecten irradians concentricus Say. J. exp. mar. Biol. Ecol. 127; 121-140

Pohle, D. G., Bricelj, V. M., Garcia-Esquivel, Z. (1991). The eelgrass canopy: an above-bottom refuge from benthic predators for juvenile bay scallops Argopecten irradians. Mar. Ecol Prog. Ser. 74: 47-59

Roughgarden, J., Gaines, S., Possingham, H. (1988). Recruitment dynamics in complex life cycles. Science 241 $1460-1466$

Sammarco, P. W., Andrews, J. C. (1989). The HELIX experiment: differential localized dispersal and recruitment patterns in Great Barrier Reef corals. Limnol. Oceanogr. 34 $896-912$

Sastry, A. N. (1963). Reproduction of the bay scallop, Aequipecten irradians Lamarck. Influence of temperature on maturation and spawning. Biol. Bull. 125: 146-153

Sastry, A. N. (1966). Temperature effects in reproduction of the bay scallop, Argopecten irradians Lamarck. Biol. Bull. 130: $118-134$

Shulman, M. J., Ogden, J. C. (1987). What controls tropical reef fish populations: recruitment or benthic mortality? An example in the Caribbean reef fish Haemulon flavolineatum. Mar. Ecol. Prog. Ser. 39: 233-242

Summerson, H. C., Peterson, C. H. (1990). Recruitment failure of the bay scallop. Argopecten irradians concentricus,

This article was presented by K. R. Sherman, Narragansett, Rhode Island, USA during the first red tide, Ptychodiscus brevis, outbreak recorded in North Carolina. Estuaries 13: 322-331

Sutherland, J P. (1987). Recruitment limitation in a tropical intertidal barnacle, Tetraclita panamensis (Pilsbry), on the Pacific coast of Costa Rica. J. exp. Mar. Biol. Ecol. 113: $267-282$

Tester, P. A., Stumpf, R. P., Vukovich, F. M., Fowler, P. K., Turner, J. T (1991). An expatriate red tide bloom: transport, distribution, and persistence. Limnol. Oceanogr. 36: 1053-1061

Tettelbach, S. T., Wenczel, P. (1991). Reseeding efforts and the status of bay scallop populations in New York following the appearance of brown tide. J. Shellfish Res. 10:273

Thayer, G. W., Stuart, H. H. (1974). The scallop makes its bed of eelgrass. Mar. Fish. Rev. 36: 27-39

Thorson, G. (1950). Reproductive and larval ecology of marine bottom invertebrates. Biol. Rev. 25: 1-45

Underwood, A. J., Denley, E. J. (1984). Paradigms, explanations and generalizations in models for the structure of intertidal communities on rocky shores. In: Strong, D. R. Jr, Simberloff, D., Abele, L. G., Thistle, A. B. (eds.) Ecological communities: conceptual issues and the evidence. Princeton University Press, Princeton, p. 151-180

Victor, B. C. (1986). Larval settlement and juvenile mortality in a recruitment-limited coral reef fish population. Ecol. Monogr. 56: 145-160

Warner, R. R., Chesson, P. L. (1985). Coexistence mediated by recruitment fluctuations: a field guide to the storage effect. Am. Nat. 125: 769-787

Wilson, W. H. Jr (1991). Competition and predation in marine soft-sediment communities. A. Rev. Ecol. Syst. 21: 221-241

Wolff, M. (1988). Spawning and recruitment in the Peruvian scallop Argopecten purpuratus. Mar. Ecol. Prog. Ser. 42: 213-217

Woodin, S. A. (1976). Adult-larval interactions in dense infaunal assemblages: patterns of abundance. J. mar. Res. 34: $25-41$

Yoshioka, P. M. (1982). Role of planktonic and benthic factors in the population dynamics of the bryozoan Membranipora membranacea. Ecology 63: 457-468

Manuscript first received: July 8, 1992

Revised version accepted: November 3, 1992 